\title{
Androgenic Regulation of Steroid Hormone Receptor mRNAs in the Brain of Whiptail Lizards
}

\author{
J. Godwin, * V. Hartman, P. Nag and D. Crews \\ Department of Zoology, University of Texas at Austin, Austin, TX, USA. \\ Key words: steroid receptor, gene expression, sexual behaviour, autoregulation, androgen, progesterone, reptile, lizard.
}

\begin{abstract}
Sex and species differences in androgenic regulation of steroid hormone receptor mRNAs were examined in the diencephalon of two species of whiptail lizards: Cnemidophorus inornatus is a sexual species and the direct evolutionary ancestor to Cnemidophorus uniparens, an all-female parthenogenetic species. Lizards were gonadectomized and treated with different doses of either aromatizable testosterone or nonaromatizable dihydrotestosterone. The relative abundances of androgen-, oestrogen-, and progesterone-receptor mRNAs were compared in various nuclei following in situ hybridization with homologous riboprobes. A diversity of patterns in androgenic regulation was observed, with effects differing according to brain region, the steroid-receptor mRNA being considered and, in some cases, between androgens. In the ancestral sexual species, intact males had lower androgen-receptor mRNA abundances than castrated, blank-implanted males in the medial preoptic area. Testosterone significantly decreased androgen-receptor mRNA abundance in the medial preoptic area of castrated males. Males had higher androgen-receptor mRNA levels in the preoptic area than females generally and neither the sexual or parthenogenetic females showed a decrease in androgen-receptor mRNA with androgen treatment. Both testosterone and dihydrotestosterone increased oestrogen-receptor mRNA abundance in the ventromedial hypothalamus of $C$. inornatus, but no sex differences in this effect were observed. Gonadectomy decreased, whereas androgen treatment increased, progesterone-receptor mRNA abundance in the ventromedial hypothalamus. There was a sex difference in this response to androgen in the sexual species, with males having greater amounts than females in this brain area. The parthenogenetic species exhibited a similar pattern to females of the sexual species, but the levels were higher overall, possibly because Cnemidophorus uniparens is triploid. The periventricular preoptic area showed a different pattern, with testosterone treatment increasing progesterone-receptor mRNA abundance in both sexes of the sexual species and in the parthenogenetic species, while dihydrotestosterone did not. The diversity of patterns in androgen effects indicates that gonadal sex, aromatization of androgen, and perhaps gene dosage all influence the expression of steroidreceptor mRNAs in the lizard brain.
\end{abstract}

Sex-steroid hormones exert their effects primarily by binding to specific intracellular receptors. These complexes bind to specific response elements in the upstream, untranslated regions of target genes and regulate expression of these genes. A hormonal stimulus is necessary in most cases for the display of sexual behaviour. The sequence of events by which steroid hormones alter gene expression, the conserved nature of both the neural substrates of sexual behaviour and the distribution of sex-steroid hormone receptors in the brain are becoming increasingly well understood. Steroid effects on sexual behaviour therefore provide an important and useful model of how hormonal signals influence individual neurones and the behavioural consequences of these influences.

We have pursued the question of steroid regulation of sexual behaviours in an ancestor/descendant pair of lizard species from the desert grasslands of South-western North America. The descendant species is Cnemidophorus uniparens and Cnemidophorus inornatus is its direct evolutionary

Correspondence to: D. Crews, Department of Zoology, University of Texas at Austin, Austin, TX 78712, USA (e-mail: crews@mail.utexas.edu). *Present address: Department of Zoology, North Carolina State University, Raleigh, NC 27695-7617, USA.

(C) 2000 Blackwell Science Ltd 
ancestor (1). Cnemidophorus uniparens is an all-female, obligately parthenogenetic species while $C$. inornatus is a sexually reproducing species with both males and females. Although C. uniparens consists entirely of females, individuals regularly display both female-like and male-like pseudosexual behaviour which is indistinguishable from the sexual behaviour displayed by $C$. inornatus females and males, respectively ( 2 , $3)$. In contrast, female $C$. inornatus rarely exhibits maletypical courtship or copulatory behaviours. The parthenogenetic species is sensitive to exogenous androgens, responding to both testosterone and dihydrotestosterone with male-like pseudosexual behaviour (4), yet androgens are not detectable in the circulation. Instead, male-like pseudosexual behaviour is activated by the surge in circulating concentrations of progesterone associated with ovulation (5).

The occurrence in these parthenogenetic females of progesterone-induced courtship and copulatory behaviours typically associated with gonadal males was initially considered unique in vertebrates. Indeed, progesterone traditionally has been regarded as an antiandrogen, acting centrally to inhibit sexual behaviour in males. However, experiments with several lizard species $(6-11)$, fish $(12)$, as well as rats $(13,14)$ challenged this paradigm. For example, systemic or intracranial implantation of progesterone into the anterior hypothalamus/preoptic area can completely restore sexual behaviour in castrated male $C$. inornatus (7-10) and modifies levels of androgenreceptor mRNA (AR mRNA) and progesterone-receptor mRNA (PR mRNA) in the preoptic area, amygdala, and lateral septum (6). This suggests that progesterone differentially regulates both its own receptor and androgen receptors in brain areas involved in the control of sexual behaviour of males.

Since the hormonal trigger for mating behaviour in male C. inornatus and in the descendant parthenogenetic $C$. uniparens differs, a better understanding of how androgens regulate oestrogen-receptor mRNA (ER mRNA), AR mRNA and PR mRNA in various diencephalic nuclei may give insight into the neuroendocrine substrates of male-typical and malelike sexual behaviour in these species. We addressed four questions in this study. First, what are the patterns of androgenic regulation of steroid hormone-receptor mRNAs in the brain of Cnemidophorus? Second, are there differences in effects between an aromatizable androgen (testosterone) and a nonaromatizable androgen (dihydrotestosterone)? Third, are there sexual dimorphisms in the androgenic regulation in Cnemidophorus? Fourth, if there are sex differences in androgen regulation of these mRNA species, does the descendant parthenogen species showing male-like pseudosexual behaviour exhibit a pattern of regulation that is more similar to females or males? Of particular interest are differences in the preoptic area of the hypothalamus, the primary integrative area for the display of male-typical sexual and male-like pseudosexual behaviour in these species.

\section{Materials and methods}

\section{Animals}

Male and female $C$. inornatus were captured near Sanderson, Texas $(C$ inornatus) or Portal, Arizona (C. uniparens), transported to the University of Texas, and maintained in envoironmental chambers under conditions simulat- ing the breeding season as described previously; before the experiment, lizards were housed in groups (15).

\section{Gonadectomy and hormone treatment}

The gonads were removed and the lizards held in social isolation as described previously (16) for 7-10 days to allow metabolic clearance of endogenous gonadal steroids. An additional 'intact' group of $C$. inornatus males was not surgically manipulated. Five different treatments were employed in gonadectomized lizards. The exogenous hormone treatments consisted of the implantation of Silastic capsules (1.47 $\mathrm{mm}$ inner diameter, $1.96 \mathrm{~mm}$ outer diameter) containing either crystalline testosterone or dihydrotestosterone; empty capsules served as controls. The hormone capsules were packed with either one or $10 \mathrm{~mm}$ of hormone (inside length; the remaining space in the $1-\mathrm{mm}$ capsules was filled with Silastic adhesive) (7). The larger implants were intended to induce circulating androgen concentrations approximating those found in male $C$. inornatus during the breeding season, while the smaller implants were included to examine possible androgen dose effects.

\section{Tissue preparation, in situ hybridization, and silver grain quantification}

Lizards were killed $24 \mathrm{~h}$ after capsule implantation, at 1200-15.00 h. Brains were rapidly removed and kept frozen $\left(-80^{\circ} \mathrm{C}\right)$ until cryosectioning. Brains were sectioned $(20 \mu \mathrm{m})$ in series of six slides to provide a complete series through the diencephalon for hybridization to the three different riboprobes. The antisense and sense control riboprobes for AR mRNA, ER mRNA, and PR mRNA were prepared from $C$. uniparens cDNA clones using previously described techniques (17). The in situ hybridization and silver grain quantification were also performed as described previously (16-18). All samples for a given mRNA type were run together in the same in situ hybridization procedure since data from different procedures are difficult or impossible to compare directly. Data are presented from the amygdala externae, lateral septum, and medial preoptic area (mPOA) for AR mRNA, the ventromedial hypothalamus and MPOA for ER mRNA, and the ventromedial hypothalamus and the periventricular preoptic area (PvPOA) for PR mRNA (regions depicted and patterns of steroid-receptor mRNA labelling described in 17).

The protocol for quantifying silver grain densities were those used in previous studies from this laboratory $(6,16,18-21)$. Briefly, slides were briefly exposed to yield minimum hybridization signals of three times background silver grain density while also preventing overexposure (which can obscure differences between cells through a 'ceiling effect' on silver grain density). We believe that the light exposure enhances measures of mRNA levels within cells, but makes quantification of absolute numbers of cells positive for a given mRNA species unreliable in comparison to immunocytochemical methods. Therefore, data on total numbers of cells positive for various mRNA species are not presented here. We quantified silver grain density over 10 labelled cells in the mPOA, lateral septum, and PvPOA and 20 cells in the amygdala and ventromedial hypothalamus. These cells were located within single sections typically matched for neuroanatomical location. Background silver grain density was determined for each animal and each nucleus measured by moving just adjacent to an unlabelled area of each section and counting grains in 10 areas equal in size to those used for labelled cells. Other brain nuclei exhibited hybridization signals for each of these mRNA species (17), but silver grain densities were low and were therefore not quantified.

\section{Statistical analysis}

Mean silver grain densities (grains/cluster) were compared across the treatment groups by one and two-way ANOVA to compare treatment effects both within and between sexes and species. Homogeneity of variance among treatment groups was assessed using Bartlett's test. Post hoc comparisons were made either with the Dunnett test where comparisons were with the blank control group or the Tukey-Kramer HSD test where all groups were simultaneously compared. A significant difference refers to rejection of the null hypothesis at $\alpha=0.05$ unless otherwise noted. Statistical power is low in some experimental groups where sections were lost during the in situ hybridization procedure and samples sizes were consequently decreased. Statistical analyses were performed using the Systat statistical software package (Systat for Windows, version 5.1.2, Systat Inc, Evanston, IL, USA) on an Apple Macintosh computer. 
Results

\section{Androgen-receptor $m R N A$}

Castration strongly increased AR mRNA levels in the mPOA of male C. inornatus (Fig. $1 ; \mathrm{F}_{5,35}=3.61, \mathrm{P}=0.01$, blank $>$ intact and implanted groups, $\mathrm{P}<0.05$, Dunnett's test). Testosterone and dihydrotestorone decreased AR mRNA expression in the mPOA to levels not different from intact males, but these treatments did not differ from each other (Fisher's LSD test, $\mathrm{P}=0.43-0.90$ in each case). No dosage differences in this effect were seen with either androgen. The increase in AR mRNA abundance in the MPOA with gonadectomy was also sex limited, occurring only in $C$. inornatus males (one-way ANOvAs comparing AR mRNA levels across treatments for each group individually, $C$. inornatus males, $\mathrm{F}_{5,35}=$ $3.61, \mathrm{P}=0.01 ; C$. inornatus females, $\mathrm{F}_{4,24}=1.29, \mathrm{P}=0.30 ; C$. uniparens, $\mathrm{F}_{4,19}=0.73, \mathrm{P}=0.58$ ). Male $c$. inornatus also had higher AR mRNA abundance in the MPOA than female $C$. inornatus with respect to blank-implanted lizards $(\mathrm{t}=2.55, \mathrm{P}=$ 0.03 ) or across all hormonal treatments together (two-way ANOVA comparison of only $C$. inornatus males and females, sex effect, $\mathrm{F}_{1,55}=12.70, \mathrm{P}=0.01$; treatment effect, $\mathrm{F}_{4,55}=3.99, \mathrm{P}=$ 0.01 ; sex by treatment interaction effect, $\mathrm{F}_{4,55}=0.05, \mathrm{P}=0.76$ ).

No significant differences were found in either the amygdala or the lateral septum between sexes, species, or treatments (Fig. 1; $\mathrm{P}>0.05$ for all sex, species, and treatment effects as well as interaction terms relating these variables in ANOVA). Both female $C$. inornatus and $C$. uniparens showed downward trends in AR mRNA levels in the lateral septum with androgen treatment, particularly in C. uniparens, but these differences were not statistically significant.

\section{Oestrogen-receptor $m R N A$}

Levels of ER mRNA were quantified in the ventromedial hypothalamus and mPOA (Fig. 2). In gonadectomized males and females of both species, ER mRNA abundance in the mPOA was decreased by androgen treatment to levels similar to intact males, but there was no apparent effect of dosage or androgen type (two-way ANOVA with sex and treatment as variables, sex effect, $\mathrm{F}_{1,62}=0.63, \mathrm{P}=0.54$; treatment effect, $\mathrm{F}_{4,62}=2.67, \mathrm{P}=0.04$; sex by treatment interaction, $\mathrm{F}_{8,62}=$


\section{AR-mRNA}

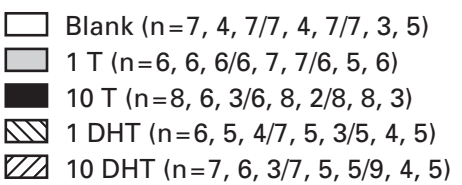

FIG. 1. Abundance of androgen-receptor mRNA (AR mRNA) measured as average number of silver grains per cluster in the amygdala externae (AMYGDALA), medial preoptic area (mPOA), and lateral septum of gonadectomized male and female little striped whiptail lizards (Cnemidophorus inornatus) and the parthenogenetic whiptail (C. uniparens) given either empty (blank) and androgen implants. Hormone treatment consisted of a 1 -mm Silastic capsule containing either 1 or $10 \mathrm{~mm}$ of testosterone $(\mathrm{T})$ or dihydrotestosterone (DHT). Means are presented with error bars $( \pm 1$ SEM $)$. For comparison, the average $( \pm 1$ SEM $)$ abundance of AR mRNA in intact males $(n=5)$ presented in horizontal stippling. Number of lizards comprising each group shown in box for each treatment group in order of presentation. 
$0.58, \mathrm{P}=0.79$ ). The 10 -mm testosterone implant group for C. uniparens showed a high value for ER mRNA abundance in the mPOA, but included only a single individual after loss of sections from other lizards. High levels of ER mRNA were not seen in the other androgen treatment groups for $C$. uniparens. Examining males or females of the two species alone did not indicate significant differences among treatment groups ( $\mathrm{P}>0.05$ for all one-way ANOVA comparisons).

The abundance of ER mRNA in the ventromedial hypothalamus was higher in $C$. uniparens than $C$. inornatus females overall. There was a suggestion of differing response to treatment between females of the two species, but this effect was not statistically significant (two-way ANOVA with species and treatment as variables, species effect, $\mathrm{F}_{1,40}=7.07, \mathrm{P}=$ 0.01 ; treatment effect, $\mathrm{F}_{4,40}=0.73, \mathrm{P}=0.57$; species by treatment interaction, $\left.\mathrm{F}_{4,40}=2.39, \mathrm{P}=0.06\right)$. No sex difference was found between male and female $C$. inornatus in ER mRNA abundances in the ventromedial hypothalamus, although androgens increased ER mRNA abundance (twoway ANOVA with sex and treatment as variables, sex effect, $\mathrm{F}_{1,52}=3.06, \mathrm{P}=0.08$; treatment effect, $\mathrm{F}_{4,52}=3.87, \mathrm{P}=0.01$; sex by treatment interaction, $\left.F_{4,52}=0.85, P=0.50\right)$. There were also much lower ER mRNA abundances in intact $C$. inornatus males than the other male treatment groups including blank-implanted lizards (one-way ANOVA comparison of males only, $\mathrm{F}_{5,33}=10.18, \mathrm{P}<0.01$; Tukey-Kramer HSD test, $\mathrm{P}<0.05)$, although blank-implanted males did not differ from hormone-treated males (Dunnett's test, $\mathrm{P}>0.05$ in all cases). No differences among treatments were found for $C$. inornatus females (one-way ANOVA, $\mathrm{F}_{4,23}=2.16, \mathrm{P}=0.11$ ) or $C$. uniparens either (one-way ANOVA, $\mathrm{F}_{4,17}=1.06, \mathrm{P}=0.40$ ), but sample sizes were quite small in some cases for $C$. uniparens.

\section{Progesterone-receptor $m R N A$}

Levels of PR mRNA were quantified in the ventromedial hypothalamus and PvPOA (Fig. 3). PR mRNA levels in the ventromedial hypothalamus were increased in females by both testosterone and dihydrotestosterone, and significant differences in response to androgen were found both between sexes and species. The relative abundance of PR mRNA was higher in $C$. uniparens than $C$. inornatus females and differed strongly between treatments, but the pattern of response did not differ between females of the two species (two-way ANOvA with species and treatment as variables, species effect, $\mathrm{F}_{1,38}=$ 5.09, $\mathrm{P}=0.03$; treatment effect, $\mathrm{F}_{4,38}=10.30, \mathrm{P}<0.01$; species by treatment interaction, $\left.\mathrm{F}_{4,38}=0.56, \mathrm{P}=0.69\right)$. Patterns of PR mRNA abundance in the ventromedial hypothalamus of $C$. inornatus differed both across sex, by treatment, and in the way the two sexes responded to treatment, with males having greater overall abundances than females and by showing a greater response to androgen treatment (two-way ANOVA with sex and treatment as variables, sex effect, $\mathrm{F}_{4,48}=$ 9.93, $\mathrm{P}<0.01$; treatment effect, $\mathrm{F}_{4,48}=9.833, \mathrm{P}<0.01$; sex by treatment interaction, $\mathrm{F}_{4,48}=3.57, \mathrm{P}=0.01$ ).

The pattern of PR mRNA expression in the PvPOA was different to that in the ventromedial hypothalamus, with androgen treatment increasing the abundance, but not differentially between sexes or species (two-way ANOVA with sex and treatment as variables, sex effect, $\mathrm{F}_{2,73}=1.12, \mathrm{P}=0.33$;

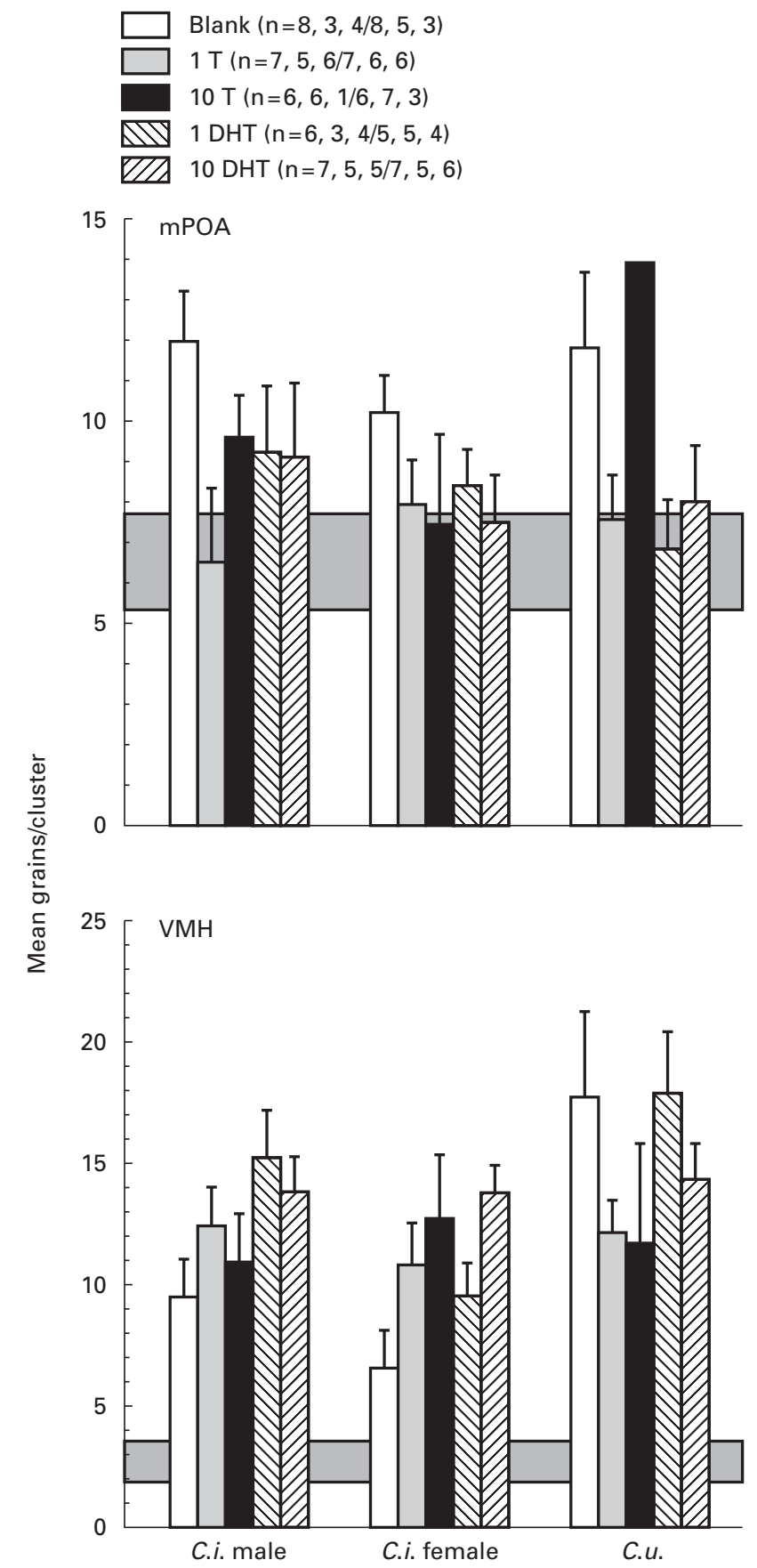

FIG. 2. Abundance of oestrogen-receptor mRNA (ER mRNA) measured as average number of silver grains per cluster in the medial preoptic area (mPOA) and ventromedial hypothalamus (VMH) of gonadectomized male and female little striped whiptail lizards (Cnemidophorus inornatus) and the parthenogenetic whiptail (C. uniparens) given either empty (blank) and androgen implants. Hormone treatment consisted of a 1-mm Silastic capsule containing either 1 or $10 \mathrm{~mm}$ of testosterone $(\mathrm{T})$ or dihydrotestosterone (DHT). Means are presented with error bars $( \pm 1$ SEM). For comparison, the average $( \pm 1$ SEM) abundance of ER mRNA in intact males presented in horizontal stippling. Number of lizards comprising each treatment group shown in box for each treatment group in order of presentation. 
PR-mRNA

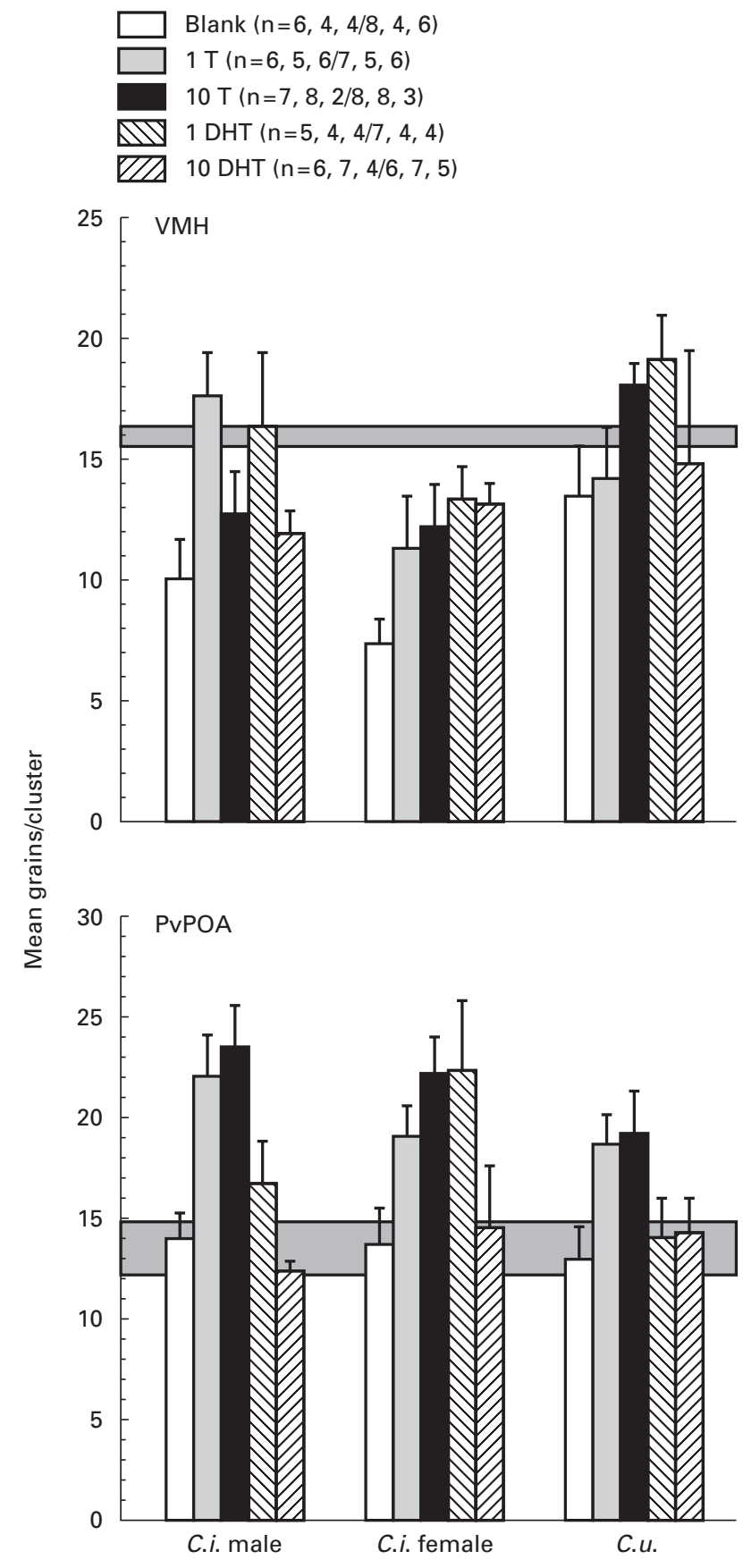

FIG. 3. Abundance of progesterone-receptor mRNA (PR mRNA) measured as average number of silver grains per cluster in the ventromedial hypothalamus $(\mathrm{VMH})$ and the periventricular preoptic area $(\mathrm{PvPOA})$ of gonadectomized male and female little striped whiptail lizards $(C$. inornatus) and the parthenogenetic whiptail (C. uniparens) given either empty (blank) and androgen implants. Hormone treatment consisted of a 1-mm Silastic capsule containing either 1 or $10 \mathrm{~mm}$ of testosterone (T) or dihydrotestosterone (DHT). Means are presented with error bars $( \pm 1$ SEM $)$. For comparison, the average $( \pm 1$ SEM $)$ abundance of PR mRNA in intact males $(n=5)$ presented in horizontal stippling. Number of lizards comprising each treatment group shown in box for each treatment group in order of presentation. treatment effect, $\mathrm{F}_{4,73}=9.55, \mathrm{P}<0.01$; sex by treatment interaction, $\left.\mathrm{F}_{8,73}=0.77, \mathrm{P}=0.62\right)$. Testosterone increased $\mathrm{PR}$ mRNA abundance in this nucleus over levels in blankimplanted and intact males while dihydrotestosterone did not (Dunnett's test, $\mathrm{P}<0.01$ ), suggesting that aromatization of testosterone to oestradiol is necessary for this effect.

\section{Discussion}

There are many parallels in the neuroendocrine control of mating behaviour between whiptail lizards and rodents. Androgens stimulate male-typical sexual behaviour in $C$. inornatus males (7) and male-like pseudosexual behaviour in C. uniparens (4). In Cnemidophorus, as in other vertebrates, the critical brain region for male-typical mounting and intromission behaviour is the anterior hypothalamus-preoptic area (AH-POA) (22). This brain area is larger in male than female $C$. inornatus and $C$. uniparens $(15,23)$. Lesions of the AH-POA abolish these behaviours in both species while intracranial implantation of androgen restores them $(24,25)$; reviewed elsewhere for other vertebrates (22). Hormones implanted directly into the AH-POA will induce gonadectomized male $C$. inornatus and $C$. uniparens to mount $(25,26)$. This brain region contains androgen receptors as well as oestrogen receptors and progestin receptors (17). The distribution of these receptors in hypothalamic nuclei is strongly phylogenetically conserved (27).

Receptive behaviour is under the control of oestrogen, and is mediated by the ventromedial hypothalamus. This brain area is larger in female $C$. inornatus and $C$. uniparens than in male $C$. inornatus $(15,23)$. Lesions of the ventromedial hypothalamus abolish receptive behaviour, whereas oestrogen implants reinstate it $(28,29)$. Finally, there is a sexual dimorphism in steroid receptor regulation in the ventromedial hypothalamus. Female $C$. inornatus respond to exogenous oestrogen treatment with receptive behaviour and with increases in the abundance of both ER-and PR mRNA in the ventromedial hypothalamus, whereas adult male $C$. inornatus do not respond either behaviourally or with alterations of these mRNAs $(19,21)$. The sexual dimorphisms in Cnemidophorus parallel sex differences in rats (30).

Testicular androgens play an important and often critical role in the control of male-typical sexual behaviour in many vertebrate animals. Given that male-typical sexual behaviour is primarily regulated by androgens in C. inornatus, we asked if a similar, but reversed, dimorphism in steroid receptor regulation to that observed in the ventromedial hypothalamus exists in the AH-POA. Specifically, are males the more responsive sex in terms of androgenic regulation of steroid receptor mRNAs in this brain area which critically regulates male-typical sexual behaviour? We found that androgens strongly decreased AR mRNA in the mPOA of males, and all four androgen treatments produced AR mRNA relative abundances in gonadectomized males which were similar to those of intact males. By contrast, the same treatments did not produce significant effects in either female $C$. inornatus or the parthenogenetic $C$. uniparens. This sex difference in response to androgen and the generally lower AR mRNA levels in the mPOA of female $C$. inornatus together suggest that this brain area is less sensitive to androgen in females 
than males. These results support the suggestion that the preoptic area, similar to the ventromedial hypothalamus, shows sexual dimorphisms in AR mRNA regulation.

It is noteworthy that a sex difference in androgenic regulation is found in the mPOA, but not in either the lateral septum or the amygdala. While both the lateral septum and amygdala strongly express AR mRNA in Cnemidophorus (17), neither region has been implicated as critical for maletypical sexual behaviour in lizards or other species. In rats, selectively blocking the androgen receptor with hydroxyflutamide implanted intracranially prevents testosterone-induced restoration of masculine copulatory behaviour when the implants are placed in the mPOA or ventromedial hypothalamus, but not when they are placed in the amygdala or lateral septum (31). We measured only silver grain density over labelled cells and not the total numbers of cells expressing these mRNAs. It is therefore possible that androgen effects on androgen receptor expression do occur in the amygdala and/or lateral septum that would be revealed with immunocytochemical or a sensitive digoxigenin-based riboprobe.

Studies of androgen receptor regulation in the brain are accumulating, but it is difficult still to draw general conclusions. Menard and Harlan (32) found that castration produced a marked decrease in AR immunoreactivity in many areas of the male rat brain, including the medial preoptic nucleus, lateral septum, amygdala and ventromedial hypothalamus. These decreases were prevented by testosterone and synthetic androgens. Castration also reduces AR immunoreactivity in the preoptic area and other forebrain sites of male Brazilian opposums, ferrets and hamsters (33-35). Measuring binding of tritiated dihydrotestosterone in brain punches from male guinea-pigs, Choate and Resko (36) found that cytosolic AR levels were increased in the POA and other areas by castration, while nuclear AR levels were decreased. Their findings appear to contrast with the increase in levels of AR mRNA in the mPOA with castration, and the prevention of this increase by both testosterone and dihydrotestosterone, reported here. However, our findings agree with those of Handa and coworkers (37). Some 4 days after gonadectomy in male rats, AR mRNA levels are increased in the MPOA relative to intact controls, but subsequently decline by 2 months after castration.

Data on AR-protein-like immunoreactivity are clearly not directly comparable to our data on AR mRNA relative abundances. There is also evidence that immunoreactivity may be influenced by the specific antibody used and by whether a receptor is occupied by ligand or not (35). Finally, androgen receptor stability is increased by ligand binding $(38,39)$. The presence of androgens may therefore strongly influence whether positive correlations between steady-state AR mRNA and AR protein levels are observed or not. A clear understanding of androgen receptor regulation will require information on effects at the transcriptional, translational, and post-translational levels.

A difference in androgen responsiveness in the mPOA of Cnemidophorus could be important in producing sex differences in behaviour. We have previously shown that an intrasexual difference in behavioural responsiveness to progesterone in $C$. inornatus males is correlated with differences in AR-and PR-mRNA responses to progesterone (6).
Importantly, intact males also have much higher circulating androgen levels than females (40) and complete male-typical sexual behaviour can be induced in both female $C$. inornatus and $C$. uniparens with testosterone implants identical to those used here $(41,42)$. The relative sensitivities of males and females to reinstatement of male-typical sexual behaviour by androgen have not been compared. Higher circulating androgen concentrations and greater sensitivity to androgen in the mPOA may both be important in restricting mounting and intromission behaviour to males in C. inornatus naturally.

Although consisting entirely of females, parthenogenetic C. uniparens frequently display male-like pseudosexual behaviour, yet have uniformly undetectable androgen levels over the course of the ovarian cycle (43). As in previous studies examining steroid receptor mRNA patterns in the hypothalamus of female Cnemidophorus (16, 18, 30), this study suggests that despite displaying male-like behaviour, C. uniparens are 'female-like' in their endocrine physiology. We had small sample sizes in some $C$. uniparens treatment groups, but found no evidence that this species shows responses to androgen that differ in pattern from those of female $C$. inornatus. Previous work suggests instead that the rise in circulating progesterone acts in the preoptic area to stimulate male-like pseudosexual behaviour (5). This study also agrees with previous work suggesting that triploidy in $C$. uniparens may produce higher steroid-receptor mRNA levels through gene dosage effects $(18,30)$. Evidence for this was seen in this study with ER and PR mRNA in the ventromedial hypothalamus where $C$. uniparens showed higher levels than C. inornatus females (Figs 2 and 3 ).

A variety of effects of androgen treatment on ER and PR mRNA expression were also seen. Androgen treatment decreased ER mRNA relative abundances in the mPOA, but we did not observe differences between sexes, species, or between the testosterone and dihydrotestosterone treatments. This effect is similar to that observed for male rats (44). Gonadectomy in male rats significantly increases the levels of ER mRNA per cell in the medial preoptic nucleus, the periventricular preoptic area, and the bed nucleus of the stria terminalis, but not the total number of cells expressing this mRNA. Lisciotto and Morrell (44) did not examine patterns in the ventromedial hypothalamus or potential sex differences in ER mRNA regulation. Synergistic actions of androgens and oestrogens on oestrogen receptors are also observed in rats. Dihydrotestosterone augments an oestradiol-induced decrease in ER-protein as measured by radioligand binding in several brain areas of gonadectomized/adrenalectomized female rats, including the mPOA and ventromedial hypothalamus, but dihydrotestosterone has no effect when administered alone (45). We did not test possible synergistic effects of oestrogens and androgens in this study, but did not find differences in the effects of testosterone and dihydrotestosterone on ER mRNA levels in the mPOA or ventromedial hypothalamus.

Since testosterone can be aromatized, it may act through androgen receptors and/or oestrogen receptors after conversion to oestradiol, while dihydrotestosterone should act solely through androgen receptors. There were no apparent differences in the effect of testosterone and dihydrotestosterone on PR mRNA abundance in the ventromedial hypothalamus, 
but testosterone increased PR mRNA in the PvPOA while dihydrotestosterone did not. This suggests that testosterone may act in the PvPOA following aromatization to oestradiol and binding to the oestrogen receptor. No significant effect of testosterone was detected on PR mRNA abundance in the PvPOA of either C. inornatus females or C. uniparens, but sample sizes were also smaller in these groups and thus our power to detect such differences was reduced relative to males. Oestrogen-induced increases in PR mRNA in the PvPOA have been demonstrated previously in female Cnemidophorus (16 46);

Oestrogen receptor mRNA levels in the ventromedial hypothalamus of intact males were much lower than in both the blank- and androgen-implanted treatment groups. This was unexpected, but there are parallels with previous findings in female Cnemidophorus. Ovariectomized females of both $C$. inornatus and $C$. uniparens have significantly higher ER mRNA levels than either vitellogenic or postovulatory intact females, yet exogenous oestradiol benzoate increases ER mRNA in these ovariectomized females (16). The higher ER mRNA levels in the ventromedial hypothalamus of castrated than intact males is similar to these findings with females, in that androgen treatment increased rather than decreased these levels. The previously suggested suppression of ER mRNA abundance in the ventromedial hypothalamus by some gonadal factor other than oestrogen or by efferent neural input could also be important for males (16), but this possibility has not been experimentally addressed.

We found that androgens regulate the abundance of steroid receptor mRNAs in various diencephalic nuclei. There are sex differences in the regulation of at least androgen receptormRNA of Cnemidophorus by androgens, complementing previous work from this laboratory showing sex differences in oestrogenic regulation of steroid receptor mRNAs in the mediobasal hypothalamus. The dimorphism in AR-mRNA regulation found here is in the AH-POA, the primary integrative centre for male sexual behaviour. Differences in androgen responsiveness might be important for normal sex differences in the display of male-typical courtship and copulatory behaviours. Finally, neither this, nor previous studies have found that patterns of steroid hormone receptor mRNAs in the descendant parthenogen $C$. uniparens are 'male' in nature. Instead, this all-female species appears to show patterns of steroid hormone receptor regulation which are similar to females of their evolutionary ancestor $C$. inornatus, despite displaying male-like pseudosexual behaviour during the luteal phase of the ovarian cycle.

\section{Acknowledgements}

We wish to thank Mo-Ping Tham for technical assistance and Ron and Sherry Hall, Ross Stavely and Frank Stavely for their hospitality and assistance with lizard collections in Sanderson, Texas, and the staff of the Southwestern Research Station of the American Museum of Natural History for logistical support in Portal, Arizona. Thanks are also due to Donald K. Clifton for providing the Grains image analysis program and Deborah Olster for comments on the manuscript. This work was supported by a NIH individual NRSA NS09219 to JG and MH41770 and NIMH Research Scientist Award MH00135 to DC.

Accepted 27 May 1998

\section{References}

1 Wright JW. Evolution of the lizards of the genus Cnemidophorus. In: Wright JW, Vitt LJ, eds. Biology of Whiptail Lizards (Genus Cnemidophorus). Herpetologist's League Special Publication no. 3. Oklahoma: Museum of Natural History, Norman, 1993: 27-82.

2 Crews D, Fitzgerald KT. 'Sexual' behavior in parthenogenetic lizards (Cnemidophorus). Proc Natl Acad Sci 1980; 77: 499-502.

3 Crews D. Unisexual organisms as model systems for research in the behavioral neurosciences. In: Dawley RM, Bogart JP, eds. Evolution and Ecology of Unisexual Vertebrates. New York: New York State Museum, Albany, 1989: 132-143.

4 Crews D, Gustafson JE, Tokarz RR. Psychobiology of parthenogenesis. In: Huey RB, Pianka ER, Schoener TW, eds. Lizard Ecology Studies of a Model Organism. Cambridge: Harvard University Press, 1983: 205-231.

5 Grassman M, Crews D. Progesterone induction of pseudocopulatory behavior and stimulus-response complementarity in an all-female lizard species. Horm Behav 1986; 20: 327-335.

6 Crews D, Godwin J, Hartman V, Grammar M, Prediger EA, Shephard R. Intrahypothalamic implantation of progesterone in castrated male whiptail lizards (Cnemidophorus inornatus) elicits courtship and copulatory behavior and affects androgen- and progesterone receptor-mRNA expression in the brain. $J$ Neurosci 1996; 16: 7347-7352.

7 Lindzey J, Crews D. Hormonal control of courtship and copulatory behavior in male Cnemidophorus inornatus, a direct sexual ancestor of a unisexual, parthenogenic lizard. Gen Comp Endocrinol 1986; 64: 411-418.

8 Lindzey J, Crews D. Effects of progestins on sexual behavior in castrated lizards (Cnemidophorus inornatus). J Endocrinol 1988; 119: 265-273.

9 Lindzey J, Crews D. Interactions between progesterone and androgens in the stimulation of sex behaviors in male little striped whiptail lizards, Cnemidophorus inornatus. Gen Comp Endocrinol 1992; 86: 52-58.

10 Lindzey J, Crews D. Effects of progesterone and dihydrotestosterone on stimulation of androgen-dependent sex behavior, accessory sex structures, and in vitro binding characteristics of cytosolic androgen receptors in male whiptail lizards (Cnemidophorus inornatus). Horm Behav 1993; 27: 269-281.

11 Young LJ, Greenberg N, Crews D. The effects of progesterone on sexual behavior in male green anole lizards (Anolis carolinensis). Horm Behav 1991; 25: 477-488.

12 Mayer I, Liley NR, Borg B. Stimulation of spawning behavior in castrated rainbow trout (Oncorhyncus mykiss) by $17 \alpha, 20 \beta$-diihydroxy4-pregnen-3-one, and not by 11-ketoandrostenedione. Horm Behav 1994; 28: $181-190$.

13 Witt DM, Young LJ, Crews D. Progesterone and sexual behavior in males. Psychoneuroendocrinology 1994; 19: 553-562.

14 Witt DM, Young LJ, Crews D. Progesterone modulation of androgendependent sexual behavior in male rats. Physiol Behav 1995; 57: 307-313.

15 Wade J, Crews D. Relationship between reproductive state and 'sexually' dimorphic brain areas in sexually reproducing and parthenogenetic whiptail lizards. J Comp Neurol 1991; 309: 507-514.

16 Young LJ, Nag Pk Crews D. Species differences in estrogen receptor and progesterone receptor-mRNA expression in the brain of sexual and unisexual whiptail lizards. J Neuroendocrinol 1995; 7: 567-575.

17 Young LJ, Lopreato GF, Horan K, Crews D. Cloning and in situ hybridization of estrogen receptor, progesterone receptor, and androgen receptor expression in the brain of whiptail lizards (Cnemidophorus uniparens and C. inornatus). J Comp Neurol 1994; 347: 288-300.

18 Young LJ, Nag PK, Crews D. Species differences in behavioral and neural; sensitivity to estrogen in the brain of the whiptail lizards: correlation with hormone receptor messenger ribonucleic acid expression. Neuroendocrinology 1995; 61: 680-686.

19 Godwin J, Crews D. Sex differences in estrogen and progesterone receptor messenger ribonucleic acid regulation in the brain of little striped whiptail lizards. Neuroendocrinology 1995; 62: 293-300.

20 Hartman V, Crews D. Sociosexual stimuli affect ER- and PR-mRNA abundance in the hypothalamus of all-female whiptail lizards. Brain Res 1996; 741: 344-347.

21 Wennstrom K, Crews D. Effect of long-term castration and long-term androgen treatment on sexually dimorphic estrogen-inducible progesterone receptor mRNA levels in the ventromedial hypothalamus of whiptail lizards. Horm Behav 1998; 34: 11-17.

22 Meisel RL, Sachs B 1994 The physiology of male sexual behavior. In: 
606 Androgen regulation of androgen- and progesterone-receptor expression in lizards

Knobil E, Neill J, eds. The Physiology of Reproduction, vol. 2. New York: Raven Press, 1994: 3-106.

23 Crews D, Wade J, Wilczynski W. Sexually dimorphic areas in the brain of whiptail lizards. Brain, Behav Evol 1990; 36: 262-270.

24 Kingston PA, Crews D. Role of the AH-POA in the control of courtship and copulatory behavior in sexual and unisexual whiptail lizards. Brain Res 1994; 643: 349-351.

25 Rozendaal JC, Crews D. Effects of intracranial implantation of dihydrotestosterone on sexual behavior in male Cnemidophorus inornatus, a direct sexual ancestor of a parthenogenetic lizard. Horm Behav 1987; 23: 194-202.

26 Mayo ML, Crews D. Neural control of male-like pseudocopulatory behavior in the all-female lizard, Cnemidophorus uniparens: effects of intracranial implantation of dihydrotestosterone. Horm Behav 1987; 21: $181-192$.

27 Pfaff DW, Schwartz-Giblin S, McCarthy MM, Kow L-M. Cellular and molecular mechanisms of female reproductive behaviors. In: Neill JD, Knobil E, eds. The Physiology of Reproduction, vol. 2. New York: Raven Press, 1994: 107-220.

28 Kendrick AM, Rand MS, Crews D. Electrolytic lesions of the ventromedial hypothalamus abolish sexual receptivity in female whiptail lizards, Cnemidophorus uniparens. Brain Res 1995; 680: 226-228.

29 Wade J, Crews D. The effects of intracranial implantation of estrogen on receptivity in sexually and asexually reproducing female whiptail lizards, Cnemidophorus uniparens and C. inornatus. Horm Behav 1991; 25: $342-353$.

30 Young LJ, Crews D. Comparative neuroendocrinology of steroid receptor gene expression and regulation: Relationship to physiology and behavior. Trends Endocrinol Metabol 1995; 6: 317-323.

31 McGinnis MY, Williams GW, Lumia AR. Inhibition of male sex behavior by androgen receptor blockade in preoptic area or hypothalamus, but not amygdala or septum. Physiol Behav 1996; 60: 783-789.

32 Menard CS, Harlan RE. Upregulation of androgen receptor immunoreactivity in the rat brain by adrogenic-anabolic steroids. Brain Res 1993; 622: $226-236$.

33 Iqbal J, Swanson JJ, Prins GS, Jacobson CD. Androgen receptor-like immunoreactivity in the Brazilian opposum brain and pituitary: distribution and effects of castration and testosterone replacement in the adult male. Brain Res 1995; 703: 1-18.

34 Kashon ML, Arbogast JA, Sisk CL. Distribution and hormonal regula- tion of androgen receptor immunoreactivity in the forebrain of the male European ferret. J Comp Neurol 1996; 376: 567-586.

35 Meek LR, Romeo RD, Novak CM, Sisk CL. Actions of testosterone in prepubertal and postpubertal male hamsters: dissociation of effects on reproductive behavior and brain androgen receptor immunoreactivity. Horm Behav 1997; 31: 75-88.

36 Choate JV, Resko JA. Effects of androgen on brain and pituitary androgen receptors and $\mathrm{LH}$ secretion of male guinea pigs. J Steroid Biochem Mol Biol 1996; 59: 315-322.

37 Handa RJ, Kerr JE, DonCarlos LL, McGivern RF, Hejna G. Hormonal regulation of androgen receptor mRNA in the medial preoptic area of the male rat. Mol Brain Res 1996; 39: 57-67.

38 Kemppainen JA, Lane MV, Sar M, Wilson EM. Androgen receptor phosphorylation, turnover, nuclear transport, and transcriptional activation. Specificity for steroids and antihormones. J Biol Chem 1992; 267: 968-974.

39 Zhou Z-X, Lane MV, Kemppainen JA, French FS, Wilson EM. Specificity of ligand-dependent androgen receptor stabilization: receptor domain interactions influence ligand dissociation and receptor stability. Mol Endocrinol 1995; 9: 208-218.

40 Moore MC, Crews D. Sex steroid hormones in natural populations of a sexual whiptail lizard, Cnemidophorus inornatus, a direct evolutionary ancestor of a unisexual, parthenogenic lizard. Gen Comp Endocrinol 1986; 63: 424-430.

41 Gustafson JE, Crews D. Effect of group size and physiological state of a cagemate on reproduction in the parthenogenetic lizard Cnemidophorus uniparens (Teiidae). Behav Ecol Sociobiol 1981; 8: 267-272.

42 Rand MS, Crews D. The bisexual brain: sex behavior differences and sex differences in parthenogenetic and sexual lizards. Brain Res 1994; 663: $163-167$.

43 Moore MC, Whittier JM, Billy AJ, Crews D. Male-like behavior in an all-female lizard: relationship to ovarian cycle. Anim Behav 1985; 33: $284-289$

44 Lisciotto CA, Morrell JI. Circulating gonadal steroid hormones regulate estrogen receptor mRNA in the male rat forebrain. Mol Brain Res 1993; 20: $79-90$.

45 Brown TJ, Scherz B, Hochberg RB, MacLusky NJ. Regulation of estrogen receptor concentrations in the rat brain: effect of sustained androgen and estrogen exposure. Neuroendocrinology 1996; 63: 53-60.

46 Godwin J, Crews D. Hormonal regulation of progesterone receptor mRNA expression in the hypothalamus of whiptail lizards: regional and species differences. J Neurobiol 1999; 39: 287-293. 